\title{
Study on the electricity generation performance of double chamber microbial fuel cell in coking wastewater treatment process
}

\author{
Hongduan Xie ${ }^{1, a^{*}}$ \\ ${ }^{1}$ College of environment and safety engineering, Shenyang University of chemical technology \\ Shenyang 110142 \\ axiehongduan@163.com
}

Keywords: Double chamber microbial fuel cell; coking wastewater; electricity generation

\begin{abstract}
Double chamber microbial fuel cell with anaerobic and aerobic was used in treatment of coking wastewater. The influence of electrode materials, initial COD and temperature on the power generation performance of microbial fuel cell was investigated. The results shown that, the electricity production performance of the carbon fiber electrode was high about $35 \%$ than the carbon paper electrode. when coking wastewater initial COD of $800 \mathrm{mg} / \mathrm{L}$, the operation conditions of temperature of $35 \square$, the electricity generation performance was best, the average current density is $3.5 \mathrm{~mA} / \mathrm{m}^{2}$. COD removal rate more than $70 \%$. Generate electricity in wastewater treatment, is a kind of green power industry, which has well development prospects.
\end{abstract}

\section{Introduction}

Microbial fuel cell (MFC) is the kind of device which has the ability to oxidize organic matter in wastewater and generates electricity [1]. With the increasing demand for treatment of high concentration industrial wastewater and green energy, green power generation in the wastewater treatment has been more and more studied. Jeongdong treated the food industry wastewater by microbial fuel cell achieves the energy recovery and effective treatment of wastewater at the same time [2]. In the treatment process of coking wastewater, biological treatment part is mainly composed of aerobic biological treatment and anaerobic biological treatment [3], which is consistent with the dual chamber microbial fuel cell composition. Carbon material with excellent electrical conductivity and strong adsorption ability, has become the most developed electrode materials for microbial fuel cell[4,5], this paper designed double chamber microbial fuel cell with anaerobic and aerobic combination, used for producing electricity experiments, simulation of the process in the practical wastewater treatment, and with the computer signal acquisition and monitoring, the electricity generation performance of the device under different conditions are studied.

\section{Experiment}

Double chamber microbial fuel cell system is shown in Figure 1, the reactor is made of organic glass. The cathode chamber and the anode chamber by using anaerobic treatment and aerobic system respectively. The reaction at certain temperature and controlled by a heating magnetic stirrer, the cathode chamber has microporous aeration. A single chamber is cubic, effective volume of $3000 \mathrm{~mL}$ $(100 \mathrm{~mm} \times 100 \mathrm{~mm} \times 300 \mathrm{~mm})$, electrode using the plane form, the effective area of $500 \mathrm{~cm}^{2}$. The proton exchange membrane (PEM) is connected between the cathode chamber and the anode chamber, at the junction of the effective area is about $50 \mathrm{~cm}^{2}$. The external circuit load adjustable resistor. The fuel cell voltage signal was collected by data automatic acquisition unit (DAU). Anaerobic sludge in the anode chamber is from in the digestion tank of coking plant. The COD of coking wastewater is $800 \mathrm{mg} / \mathrm{L}$. With nitrogen aeration 2 hours to remove dissolved oxygen in the aeration chamber, in order to maintain the anode system $\mathrm{pE}$ value is lower than the $-320 \mathrm{mv}$, keep the anode chamber in the anaerobic condition, suitable for the growth and metabolism of anaerobic bacteria. Aerobic sludge in the cathode chamber is from coking wastewater aerobic treatment tank. The external circuit resistance maintain of 
$60 \Omega$ by the resistor adjusting. The output voltage $(\mathrm{V})$ of battery is automatically recorded by the data acquisition system, $\mathrm{I}=\mathrm{V} / \mathrm{R}$, where $\mathrm{R}$ is the resistance. of $\rho \mathrm{I}=\mathrm{I} / \mathrm{A}$, where $\mathrm{I}$ is the current density, $\mathrm{A}$ is the effective area of electrode, $\rho I$ is the current density.

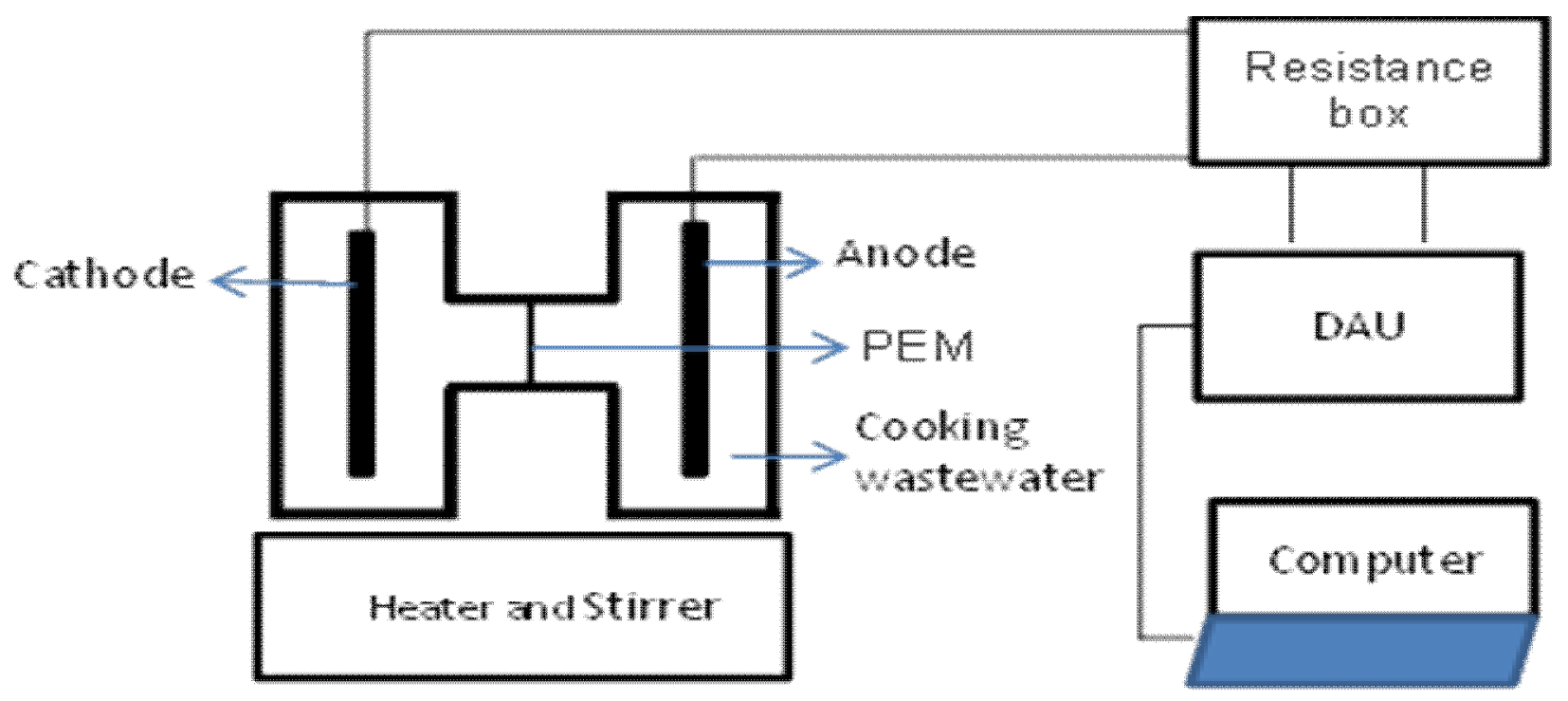

Fig. 1 The scheme of the experiment

\section{Result and discussion}

Effects of electrode materials on the electricity generation performance of microbial fuel cell

The electrode material and structure is directly related to the electron transport rate of the battery internal resistance, has a significant impact on the electrical properties ${ }^{[4]}$. This experiment mainly studied two kinds of electrode materials. One is ordinary carbon paper, another is carbon fiber felt with the same effective area. Compared with traditional carbon paper electrode, carbon fiber has higher specific surface area and porosity of the advantages. Two experiments are carried out on the COD is $800 \mathrm{mg} / \mathrm{L}$ and the external resistance is $60 \Omega$ conditions. The electricity production performance is shown in figure 2 .

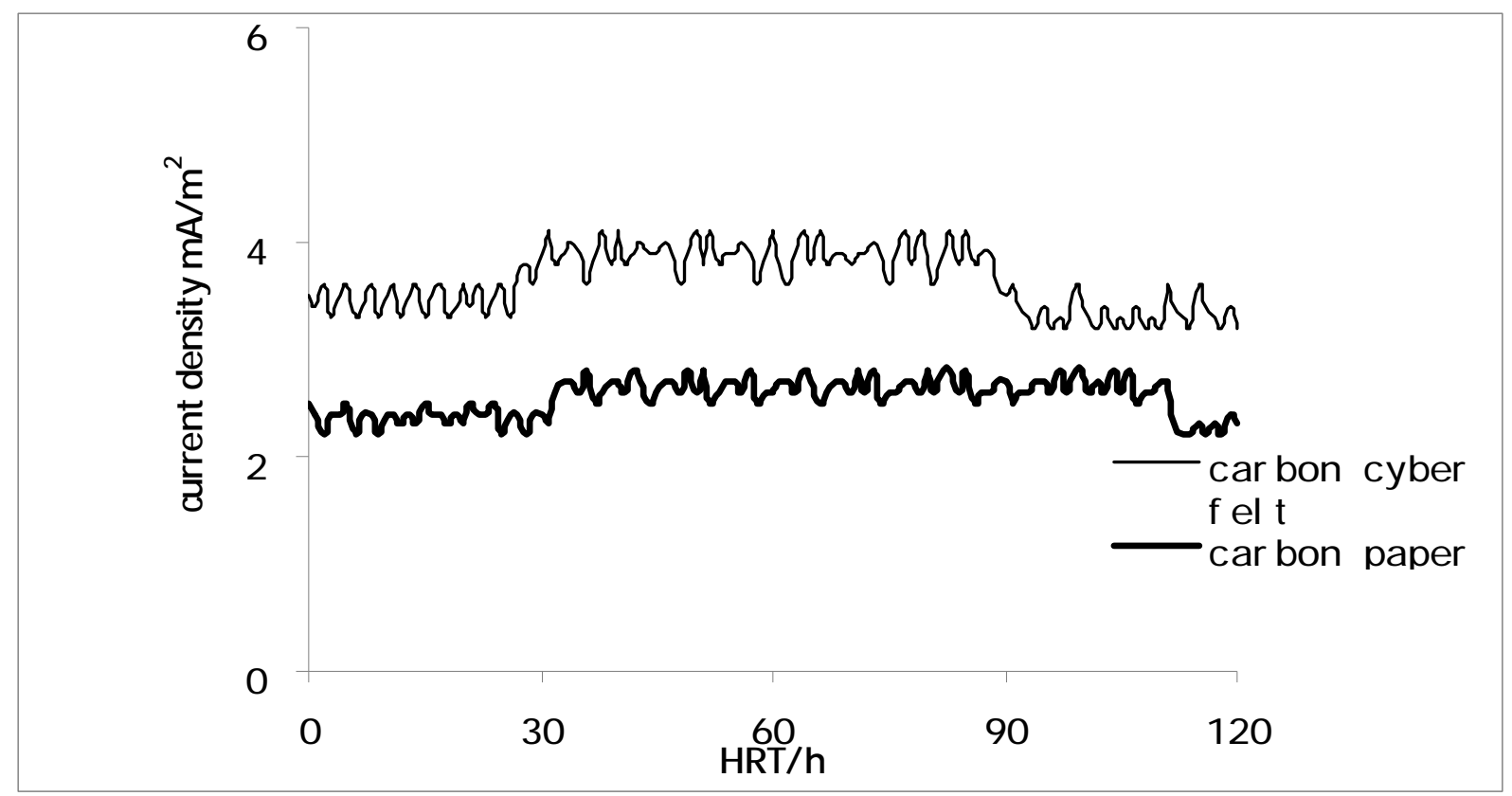

Fig.2 Effects of electrode materials on the electricity generation performance of microbial fuel cell 
From Fig. 2 we can see, the stability is better than that of carbon paper electrode carbon fiber electrode electricity production, in the later stage of the trend is more obvious, the average current density of carbon fiber electrode outside the road is 30\% higher than that of carbon paper electrode, reached $3.6 \mathrm{~mA} / \mathrm{m} 2$.

Effect of wastewater COD on the electricity generation performance of microbial fuel cell

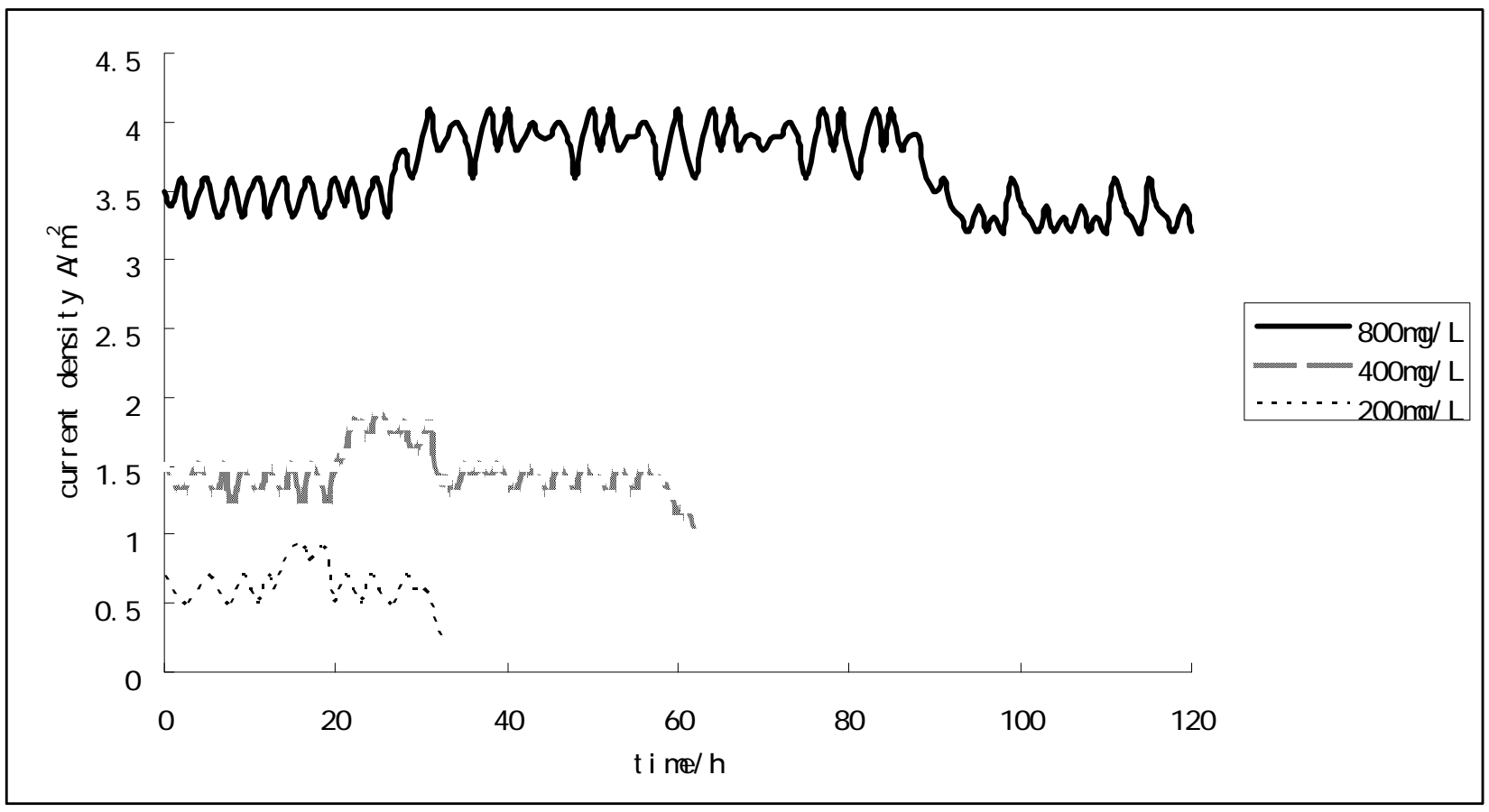

Fig.3 Effect of wastewater COD on the electricity generation performance of microbial fuel cell

The coking wastewater COD value of water is adjusted to $800 \mathrm{mg} / \mathrm{L}, 400 \mathrm{mg} / \mathrm{L}, 200 \mathrm{mg} / \mathrm{L}$. Effect of COD on the microbial fuel cell by external current density as shown in figure 3 . When the COD was $200 \mathrm{mg} / \mathrm{L}$, current density of the cells increased with time increase, up to a maximum value at $14 \mathrm{~h}$ after operation, the current density is about $0.9 \mathrm{~mA} / \mathrm{m}^{2}$. The Highest electricity production was maintaining 4 $\mathrm{h}$ then gradually to decline; the running time is about $20 \mathrm{~h}$ when reduced to the initial level. With the increase ofCOD, stable electricity production time and current density showed a clear upward trend of battery. When COD is $400 \mathrm{mg} / \mathrm{L}$, the current density of the battery is about $1.5 \mathrm{~mA} / \mathrm{m}^{2}$; highest value appeared at the 23 hours, stable electricity production time is about 60 hours. In COD $800 \mathrm{mg} / \mathrm{L}$, the current density is about $3.5 \mathrm{~mA} / \mathrm{m}^{2}$. Stable electricity production time reached 120 hours. During the whole experiment time, the removal rate of COD was stable above at $70 \%$.

\section{Effect of temperature on the power generation performance}

Temperature is an important factor affecting microbial metabolic activities, therefore, different temperature can produce different electricity, the results are shown in figure 4 . We can see from Figure 4 , the temperature affects the whole system of electricity production is obvious, when the temperature is $35 \square$ electricity production effect is the best, this may be because of aerobic and anaerobic microorganisms in the treatment system of $35{ }^{\circ} \mathrm{C}$ the highest microbial activity, metabolism, temperature is too high or too low, the microbial activity is suppressed. Under the optimal temperature, the removal rate of COD is above $70 \%$, realist the recovery of electric energy and the treatment of wastewater at the same time. 


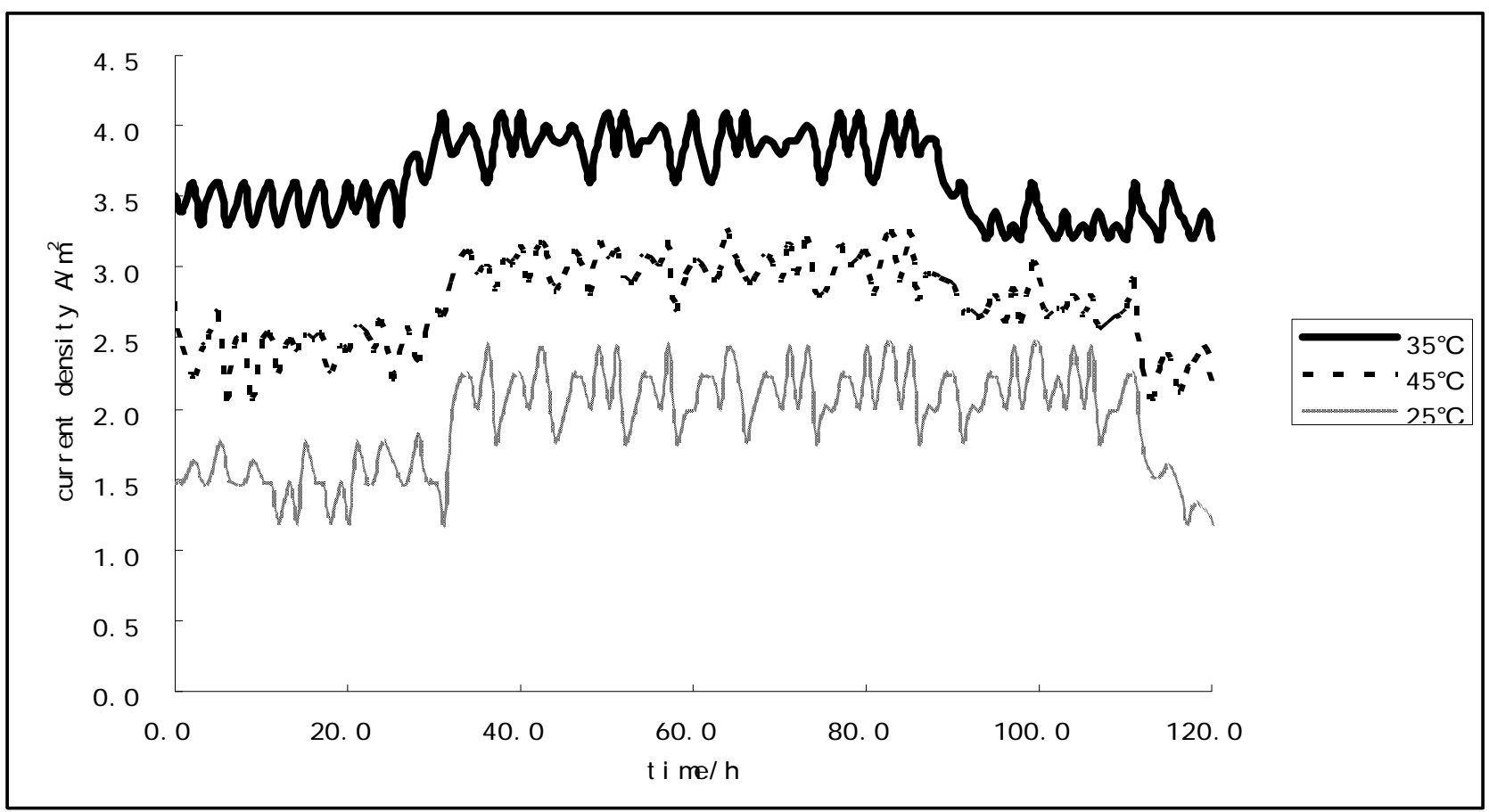

Fig.4 Effect of temperature on the power generation performance

\section{Summary}

Coking wastewater treated by double chamber microbial fuel cell can get the stable output current, electricity produced by carbon fiber felt electrode is high about 35\% more than the carbon paper electrode, coking wastewater initial COD of $800 \mathrm{mg} / \mathrm{L}$, the operation conditions of temperature of $35 \square$, the electricity generation performance best, the average current density is $3.5 \mathrm{~mA} / \mathrm{m}^{2}$. Generate electricity in wastewater treatment.

\section{Acknowledgements}

This work was financially supported by the Education Commission of Liaoning Province Foundation (L2012140)

\section{References}

[1]V.M.Ortiz-Martínez, M.J. Salar-García, A.P. de los Ríos, et al. Developments in microbial fuel cell modeling [J]. Chemical Engineering Journal,2015,(271):50-60.

[2] Jeongdong Choi, Youngho Ahn. Enhanced bioelectricity harvesting in microbial fuel cells treating food waste leachate produced from biohydrogen fermentation.Bioresource Technology, 2015(183):53-60.

[3] SongZhiwei ZhangFurong QuZhi. Influence of $\mathrm{A} / \mathrm{O}$ and $\mathrm{A}_{2} / \mathrm{O}$ process on coking wastewater treatment.Chinese Journal of Environmental Engineerin,2009,12(3):2198-2202.

[4]Elnaz Halakoo, Alireza Khademi, Mostafa Ghasemi, et al. Production of Sustainable Energy by Carbon Nanotube/Platinum Catalyst in Microbial Fuel Cell. 12th Global Conference on Sustainable Manufacturing Procedia, CIRP 2015(26):473-476

[5] Zhidan Liu, Yanhong He, Ruixia Shen, et al. Performance and microbial community of carbon nanotube fixed-bed microbial fuel cell continuously fed with hydrothermal liquefied cornstalk biomass, Bioresource Technology, 2015(185) 294-301. 